\title{
Lymphocyte subset reference intervals in blood donors from northeastern Brazil
}

\author{
ALEX J.L. TORRES ${ }^{1,9}$, PATRÍCIA CISNEIROS ${ }^{2,9}$, ROSA GUEDES ${ }^{2}$,

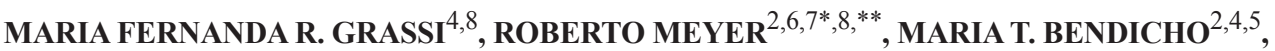 \\ TAIS G.S.L. LOPES ${ }^{1,10}$, GABRIELA FÉLIX ${ }^{1}$, EDUARDO M. NETTO ${ }^{2,6}$, \\ CARLOS BRITES ${ }^{2,6,7^{*}, * *}$, KIYOKO ABE-SANDES $^{1,5}$, CLAUDIO BRANDÃO $^{3,9}$, \\ NEUZA ALCANTARA-NEVES ${ }^{6, * *}$ and SONGELI M. FREIRE ${ }^{2,4,6,7 *}, 10,{ }^{* *}$ \\ ${ }^{1}$ Hospital Universitário Professor Edgard Santos, UFBA, Laboratório de Pesquisa em \\ Infectologia, Rua Augusto Vianna, s/n, Canela, 40110-160 Salvador, BA, Brasil \\ ${ }^{2}$ Instituto de Ciências da Saúde, UFBA, Laboratório de Imunologia e Biologia Molecular, \\ Av. Reitor Miguel Calmon, s/n, Vale do Canela, 40110-903 Salvador, BA, Brasil \\ ${ }^{3}$ Fundação de Hematologia e Hemoterapia da Bahia (HEMOBA), \\ Hospital Geral, Lad, nº 0, Brotas, 40286-240 Salvador, BA, Brasil \\ ${ }^{4}$ Escola Bahiana de Medicina e Saúde Pública (EBMSP), Av. \\ Dom João VI, 295, Brotas, 40285-000 Salvador, BA, Brasil \\ ${ }^{5}$ Departamento de Ciências da Vida, Universidade do Estado da Bahia (UNEB), \\ Rua Silveira Martins, 2555, Cabula, 41150-000 Salvador, BA, Brasil \\ ${ }^{6}$ Instituto de Ciências da Saúde, Universidade Federal da Bahia (UFBA), Av. \\ Reitor Miguel Calmon, s/n, Vale do Canela, 40110-903 Salvador, BA, Brasil \\ ${ }^{7}$ Instituto Nacional de Ciência e Tecnologia em Doenças Tropicais (INCT-DT), \\ Ministério da Ciência, Tecnologia e Inovação, Rua Augusto Vianna, s/n, \\ Serviço de Imunologia, $5^{\circ}$ andar, Canela, 40110-160 Salvador, BA, Brasil \\ ${ }^{8}$ Ministério da Saúde, Fundação Oswaldo Cruz, Laboratório Avançado de Saúde Pública, \\ Rua Waldemar Falcão, 121, Candeal, 40296-710 Salvador, BA, Brasil \\ ${ }^{9}$ Programa de Pós-Graduação em Imunologia, ICS/UFBA, Av. Reitor Miguel Calmon, \\ s/n, Vale do Canela, 40110-903 Salvador, BA, Brasil \\ ${ }^{10}$ Programa de Pós-Graduação em Processos Interativos dos Órgãos e Sistemas, ICS/UFBA, \\ Av. Reitor Miguel Calmon, s/n, Vale do Canela, 40110-903 Salvador, BA, Brasil
}

Manuscript received on April 15, 2013; accepted for publication on June 4, 2014

\begin{abstract}
The reference intervals for leukocytes and lymphocytes currently used by most clinical laboratories present limitations as they are primarily derived from individuals of North American and European origin. The objective this study was to determine reference values for peripheral blood B lymphocytes, $\mathrm{T}$ lymphocyte subsets (CD4+, CD $8+$, naïve, memory, regulatory, TCR $\alpha \beta$ and TCR $\gamma \delta+)$ and NK cells from blood donors in Salvador-Bahia, Brazil. Results: The proportion of included male subjects was $73.7 \%$ and the median
\end{abstract}

Correspondence to: Songeli Menezes Freire

E-mail: songeli@ufba.br

$* \mathrm{CNPq} / \mathrm{MCT}$

** $\mathrm{CNPq}$ 
ages of males (34) and females (35) were found to be similar. Absolute counts total lymphocytes subsets to both gender was $1,956(1,060-4,186)$ cells and relative values $34 \%$. The T CD4+ and T CD8+ lymphocytes relative values was $51 \%(20-62)$ and $24 \%(9-28)$, respectively. The most statistically significant finding observed was a higher percentage of B lymphocytes $(p=0.03)$ in females. Commonly cited subset reference intervals were found to be consistent with values in several populations from different geographic areas.

Key words: lymphocyte subsets, reference values, flow cytometry, Brazil, blood donors.

\section{INTRODUCTION}

The quantification of diverse cellular subpopulations facilitates the monitoring of infectious, autoimmune and hematologic diseases. Reference intervals obtained from $\mathrm{CD}^{+}$and $\mathrm{CD} 8^{+} \mathrm{T}$ lymphocyte subsets in HIV-infected patient populations have been made available worldwide, thereby allowing for improved monitoring as well as optimized therapeutic strategies for AIDS patients (Buclin et al. 2011). Recently, the identification of markers that characterize cellular subpopulations has allowed for a more comprehensive understanding of the natural course and immunopathogenesis of some autoimmune and infectious diseases. The function of natural Tregulatory cells, which express Foxp3 (forkhead box P3) and $\mathrm{CD} 25^{+}$, is to suppress the activation, proliferation and functions of immune system effector cells (Belkayd 2007). Variations in the proportions of regulatory $\mathrm{T}$ cells in peripheral blood have been described in patients with allergies, as well as those suffering from autoimmune diseases, including polyendocrinopathy and Wiskott-Aldrich syndrome (Ochs et al. 2007), infectious diseases, such as tuberculosis (Yeh 2010), AIDS (Sachdeva et al. 2010), infectious dermatitis in association with HTLV-1 (Magalhães et al. 2011) and candidiasis (Torgerson et al. 2007). The subtype of $\mathrm{T}$ lymphocytes carrying the gamma delta receptor is more commonly found in mucous membranes, while the proportion of these cells in peripheral blood ranges from 1-5\% (Bottino et al. 1988). Higher percentages of these cells have been described in individuals exhibiting resistance, as well as protective immunity, to Mycobacterium tuberculosis and Mycobacterium leprae, in comparison to those susceptible to these infections (Barnes et al. 1992). On the other hand, active tuberculosis and HIV-infected individuals (with or without tuberculosis) have a reduced number of V $\delta 2$ T cells in comparison to healthy individuals (Bisset et al. 2004). Since the literature contains limited information regarding lymphocyte subset reference intervals obtained from healthy populations, the establishment of relevant reference values could result in a considerable contribution to the diagnosis, prognosis and monitoring of infectious, inflammatory (autoimmune and allergic), hematologic and neoplastic diseases.

Brazil, the largest country in Latin America, possesses the world's fifth-largest population. Brazilian ethnicity, or ethnic composition, is the result of complex mixing between individuals of European, Amerindian and African origin. The city of Salvador, located in the northeastern state of Bahia, was Brazil's first capital and home to many European immigrants, as well as a principal port for transporting slaves from Africa beginning in the sixteenth century. In order to attempt to elucidate reference values for peripheral blood leucocytes, particularly lymphocyte subsets, the present study evaluated a population sample of healthy blood donors from this region.

\section{METHODS}

STUDy DESIGN AND PopUlation

A cross-sectional study was conducted at the Bahia Hematology and Hemotherapy Foundation (HEMOBA) in the city of Salvador-Bahia, Brazil. HEMOBA is the largest public hemotherapy center in northeastern Brazil, with an average of 6,000 blood donor visits per month from Salvador and other regions of the state. HEMOBA accepts blood donations from individuals who are healthy in appearance, between the ages of 18-60, not taking 
medication and who have a proportionate height/ weight ratio, normal levels of blood pressure, pulse rate and hemoglobin, no past history of disease, no cough, fever or infection. All included study participants underwent a clinical evaluation and answered a questionnaire with specific questions pertaining to epidemiological and clinical criteria. All blood samples were collected in EDTA tubes and were screened, within two hours of storage at room temperature, for human immunodeficiency virus (ELISA, MUREX Ag/Ab HIV combination, Dartford, Kent, England), human T-cell lymphotropic virus (HTLV) (HTLV I\& II-Abbott-Murex, Dartford, Kent, England), hepatitis B virus (Anti-HBc, BioRad, Monalisa anti-HBc Plus-Marnes-la-Coquette, France and Murex HBsAg V3-Abbott, Dartford, Kent, England), hepatitis C virus (Hepanostika HCV Ultra-Beijing United Biomedical Co. Ltd, Shangai, China), Chagas disease (Gold ELISA Chagas, São Paulo, Brazil) and syphilis (ELISA Trepanostika $^{\mathrm{TM}}$ TP, BIOMERIEUX BV-Boxtel, Netherlands). All samples with positive serology for any of these diseases were excluded in accordance with guidelines established by the Brazilian Ministry of Health. The present study was approved by the institutional review board of the Federal University of Bahia (UFBA) and written informed consent was obtained from all study participants, who received serological test and other exam results upon request.

LEUCOCYTE COUNTS AND IMMUNOPHENOTYPING

Leukocyte counts were performed using a Sysmex SF-3000 automatic cell counter (Sysmex Corporation, Mundelein, IL, USA). Morphometric analysis was conducted under optical microscopy by a hematologist at HEMOBA.

\section{FLOW CYTOMETRY ANALYSIS}

Direct immunofluorescence labeling was performed using $100 \mu \mathrm{L}$ of whole blood samples incubated with monoclonal antibodies for $30 \mathrm{~min}$. at room temperature. Erythrocytes were subse- quently lysed with fluorescence-activated cell sorting (FACS) lysing solution (BD Biosciences Immunocytometry Systems, San Jose, CA). Cells were then washed three times in $2 \mathrm{ml}$ of phosphatebuffered saline (PBS) pH 7.4 containing 1\% bovine serum albumin. After the final wash, cells were fixed in PBS containing 4\% paraformaldehyde. T lymphocyte subsets, B lymphocytes and NK cells were quantified using a phenotypic profile described in Table I. Analyses were performed using a BD FACSCalibur flow cytometer and CellQuest ${ }^{\mathrm{TM}}$ software (BD Biosciences, San Jose, CA). No less than 105 events were analyzed per sample.

\section{STATISTICAL ANALYSIS}

Data are represented in terms of median values (interquartile ranges). Mann-Whitney $U$ test was employed to compare differences among males and females. SPSS Statistical Software (Version 13.0, SPSS Inc., Chicago, IL) was used to conduct data analysis.

The protocol was approved by the Ethical Commitee from Maternidade Climério de Oliveira Hospital, Federal University of Bahia. Informed consent was obtained from the volunteers blood donors.

\section{RESULTS}

A total of 304 blood donors were evaluated and 15 were excluded due to positive serology results following pathogen screening, resulting in an inclusion of 289 individuals. Males predominated (73.7\%) with a median age of 34 (range: 18-59), similar to females with a median of 35 (range: 18-53). Previous treatment for parasitic diseases was reported in $24.9 \%$ (males) and $35.5 \%$ (females), while allergy history was found to be similar in both sexes (approximately 15\%). The proportion of men who reported sleeping less than eight hours per night $(21.1 \%)$ was higher than in women $(5.3 \% ; p=0.002)$. More men reported a history of smoking and regular alcohol consumption, yet these findings were not statistically significant. Median WBC counts, as well as neutrophil, monocyte and eosinophil subsets are shown in Table II. 
TABLE I

Combination of antibodies used to determine lymphocyte subsets.

\begin{tabular}{cccc}
\hline \multicolumn{4}{c}{ Conjugate monoclonal antibodies } \\
\hline Lymphocyte subset & FITC (clone) & PE (clone) & PE-CY5 (clone) \\
\hline Naïve T CD4+ & CD45RA (HI100) & CD3 (HIT3a) & CD4 (RPA-T4) \\
Naïve T CD8+ & CD45RA (HI100) & CD3 (HIT3a) & CD8 (HIT8a) \\
Memory T CD4+ & CD45RO (UCHL1) & CD3 (HIT3a) & CD4 (RPA-T4) \\
Memory T CD8+ & CD45RO (UCHL1) & CD3 (HIT3a) & CD8 (HIT8a) \\
T regulatory & CD25hi (M A251) & CD4 (RPA-T4) & \\
T CD4+ TCR $\alpha \beta$ & TCR $\alpha \beta($ T10B9.1A-31) & CD3 (HIT3a) & CD4 (RPA-T4) \\
T CD8+ TCR $\alpha \beta$ & TCR $\alpha$ (T10B9.1A-31) & CD3 (HIT3a) & CD8 (HIT8a) \\
TCD4+ TCR $\gamma \delta$ & TCR $\gamma \delta(B 1)$ & CD3 (HIT3a) & CD4 (RPA-T4) \\
LTCD8+ TCR $\gamma \delta$ & TCR $\gamma \delta(B 1)$ & CD3 (HIT3a) & CD8 (HIT8a) \\
B & CD20 (2H7) & CD19 (HIB19) & \\
NK & & CD56 (B159) & CD16 (3G8) \\
\hline
\end{tabular}

FITC: Fluorescein isothiocyanate; PE: Phycoerythrin; PE-CY5; Phycoerythrin-Cy5.

All monoclonal antibodies were obtained from BD.

TABLE II

White blood cell (WBC) and WBC subset counts from blood donors from northeastern Brazil.

\begin{tabular}{c|c|c|c|c|c|}
\hline Cell subset & \multicolumn{2}{|c|}{ Male } & \multicolumn{2}{c|}{ Female } & \multirow{2}{*}{ P } \\
\hline & cells/ mm3 & \% & cells/ mm3 & \% & \\
WBC & $5,900(3,231-10,405)$ & & $6,245(3,275-11,551)$ & & \\
Neutrophils & $3,115(1,270-6,625)$ & $54(32-72)$ & $3,580(1,411-7,910)$ & $58(33-76)$ & $<0.05$ \\
Lymphocytes & $1,935(1,060-3,380)$ & $34(17-57)$ & $1,975(1,132-4,186)$ & $33(14-55)$ & \\
Monocytes & $400(163-1,636)$ & $6(3-13)$ & $335(138-673)$ & $5(3-13)$ & $<0.05$ \\
Eosinophils & $195(40-1,636)$ & $5(0.7-19)$ & $155(19-2,146)$ & $3(0.3-23)$ & $<0.05$ \\
Basophils & $30(3-70)$ & $1(0.3-1)$ & $30(0-123)$ & $1(0-1)$ & \\
\hline
\end{tabular}

Data represent median values $\left(2.5^{\text {th }}\right.$ and $97.5^{\text {th }}$ percentile $)$ reference intervals. $p<0.005$ Mann-Whitney U-test.

No statistically significant differences were found in any of these cell counts when comparing among male and female blood donors. Table III describes the reference values obtained from lymphocyte subpopulations. No statistically significant differences were detected between sexes with respect to the proportions of lymphocyte subsets, the only exception being a higher proportion of B lymphocytes in females compared to males (Table III).

\section{DISCUSSION}

In contrast to previous studies, which have primarily focused on isolated $\mathrm{T}$ cell subsets, the present study represents the first attempt to establish lymphocyte subset reference intervals from peripheral blood samples in healthy blood donors from northeastern Brazil, specifically with respect to naïve and memory $\mathrm{CD}^{+}$and $\mathrm{CD}^{+} \mathrm{T}$ cells, as well as to $\alpha \lambda \phi \alpha \beta \varepsilon \tau \alpha$ and $\gamma \alpha \mu \mu \alpha \delta \varepsilon \lambda \tau \alpha \mathrm{T}$ lymphocyte and $\mathrm{CD} 25^{+} \mathrm{T}$ lymphocytes. The subset values of naïve and memory $\mathrm{CD}^{+}$and $\mathrm{CD} 8^{+} \mathrm{T}$ lymphocytes were found to be lower than those established by Bisset et al. in healthy adults from Switzerland (Bisset et al. 2004). However, these authors used different markers to quantify naïve $\mathrm{CD} 4^{+} \mathrm{T}$ lymphocytes. The percentage of regulatory $\mathrm{T}$ cells was around $2-5 \%$ of $\mathrm{CD}^{+} \mathrm{T}$ lymphocytes, as was previously described in other populations (Bottino et al. 1988, Hirahara et al. 2006, Borrego et al. 2007). The values of B lymphocytes and NK cells obtained 
TABLE III

Proportion of B-lymphocytes, NK cells and T-lymphocyte subsets from blood donors from northeastern Brazil.

\begin{tabular}{cccc}
\hline & \multicolumn{3}{c}{$\%$ of total lymphocytes } \\
\cline { 2 - 4 } Lymphocyte subsets & Male & Female & P \\
\hline Naive T CD4+ & $19(11-27)$ & $17(8-34)$ & 0.082 \\
Memory T CD4+ & $19(12-33)$ & $21(13-37)$ & 0.205 \\
Naive T CD8+ & $11(3-23)$ & $11(3-20)$ & 0.297 \\
Memory T CD8+ & $7(3-17)$ & $8(4-22)$ & 0.289 \\
T CD4+ TCR $\alpha \beta^{£}$ & $51(20-63)$ & $52(38-62)$ & 0.644 \\
T CD8+ TCR $\alpha \beta^{£}$ & $24(9-25)$ & $24(18-28)$ & 0.070 \\
T CD4+ TCR $\gamma \delta^{£}$ & $3(1-4)$ & $3(1-4)$ & 0.078 \\
T CD8+ TCR $\gamma \delta^{£}$ & $2(1-2)$ & $2(1-2)$ & 0.708 \\
B Lymphocytes & $8(3-19)$ & $11(3-26)$ & 0.019 \\
NK cells** & $13(2-28)$ & $15(3-27)$ & 0.372 \\
Treg cells*** & $5(4-9)$ & $4(2-8)$ & 0.861 \\
\hline
\end{tabular}

Data represent median $\left(2.5^{\text {th }}-97.5^{\text {th }}\right.$ percentiles $)$ reference intervals from 158 individuals (112 male and 46 female). Treg: Regulatory T cells $\left(\mathrm{CD} 4{ }^{+}, \mathrm{CD} 25 \mathrm{hi}^{+}\right) .{ }^{£}$ Data available for 116 individuals ( 78 male and 38 female). ${ }^{* *}$ Data available for 128 individuals (94 male and 34 female). $* * *$ Data available for 47 individuals ( 31 male and 16 female). $p<0.005$ Mann-Whitney U-test.

in the present study were also similar to those described in populations with diverse genetic backgrounds from Italy (Santagostino et al. 1999), Ethiopia (Tsegaye et al. 1999), Switzerland (Bisset et al. 2004), Iran (Shahghasempour et al. 2001) and Asia (Lee et al. 1996). Furthermore, the present study successfully established reference intervals for populations of $\mathrm{T}$ lymphocytes with receptors $\alpha \beta$ and $\gamma \delta$ in peripheral blood, which is noteworthy as most studies evaluate these particular subsets exclusively in compartments, such as infiltrated tumors, solid tumors or in bronchoalveolar lavage (Han et al. 1997, Ferreira et al. 2000). Leukocyte subset reference intervals derived from peripheral blood in a sizeable population may prove useful in immunological or infectious disease modeling, as well as in the monitoring of patients suffering from these illnesses.

Total leukocyte and subset counts were found to be consistent with reference values established by three large-scale clinical laboratories in Brazil, located in São Paulo, Rio de Janeiro and Salvador (Failace 2003) as well as those confirmed in populations of other countries, such as Uganda (Lugada et al. 2004) and the UK (Wakeman et al. 2007). By contrast, the eosinophil counts herein were found to be higher than those obtained by two laboratories in São Paulo and Rio de Janeiro, the two largest and most affluent cities in Brazil (data not shown). Lugada et al. (2004) reported an increased number of eosinophils in Uganda when compared to Western populations, as well as in relation to other African populations residing in Europe. In these regions, it is possible that the eosinophil levels may vary in accordance with rates of helminth infection. However, these authors found no correlation between eosinophil counts and elevated total anti-helminth IgE (Lugada et al. 2004). In addition, a previous study involving the same individuals included in the present study found a high prevalence of seropositivity to Toxocara spp., whose infection is known to be highly associated with eosinophilia and total $\operatorname{IgE}$ (Dattoli et al. 2011). Moreover, no association between the variable of gender and cellular subset proportions/counts was detected; for example, the 
total number of neutrophils in women was similar to that of men, but different from those reported by Ngowi et al. (2008) in Tanzania (Ngowi et al. 2009), as well as by Urquhart et al. (2008) in blood donors from Jamaica (Urquhart et al. 2008).

The Brazilian population is considered to be one of the most heterogeneous in the world. With respect to the population of Salvador, $79.8 \%$ of the population classify themselves as being of African descent (IBGE 2010). An assessment of the degree of populational mixing in Salvador indicated that this population follows a tri-hybrid model of ancestral contribution: 49\% African, 44\% European and 7\% Amerindian (Felix et al. 2010) Interestingly, the elevated degree of mixing seems to have had no influence on leucocyte reference intervals or lymphocytes subset reference intervals. Although a smaller number of leukocytes has been described in populations of African descent in comparison to Caucasians (Forbes et al. 1941, Rippey 1967, Bain 1996, Pancham et al. 1999) similar values were observed in Brazilian blood donors from Salvador, as well as in reference values provided by two laboratories in São Paulo and Rio de Janeiro, cities with populations containing higher proportions of Caucasians (data not shown) than Salvador.

In conclusion, the present study successfully established relevant lymphocyte reference intervals, including important immunological subsets rarely described in the literature, in peripheral blood samples obtained from a tri-hybrid population in northeastern Brazil. In addition to new reference values for cells expressing CD25, $\mathrm{TCR} \alpha \beta$ and $\mathrm{TCR} \gamma \delta$, which were previously unreported in peripheral blood, the values obtained for commonly described subset reference intervals $\left(\mathrm{CD}^{+}, \mathrm{CD} 8^{+}, \mathrm{NK}\right.$ cells and B lymphocytes) were found to be consistent with those reported in several populations from a range of geographic areas. The significant difference between gender for B lymphocytes values was due higher total lymphocytes counts in females and proportional distribution to $\mathrm{B}$ and $\mathrm{T}$ cells and has not significant immunological expression. Further studies should be carried out to validate these findings in other populations of diverse ethnic composition.

\section{ACKNOWLEDGMENTS}

Financial support was provided by the Fundação de Amparo à Pesquisa do Estado da Bahia (FAPESB), the Laboratory of Immunology and Molecular Biology-Health Sciences Institute (UFBA); Grants from the Scientific Initiation Program and UFBA Post-Graduate Program, Conselho Nacional de Desenvolvimento Científico e Tecnológico (CNPq), Fundação de Hematologia e Hemoterapia da Bahia (HEMOBA). The authors would like to thank all volunteer blood donors, the staff and technicians from UFBA and HEMOBA, as well as Andris K. Walter for English revision and consultation services.

\section{RESUMO}

Intervalo de referências para leucócitos e linfócitos atualmente utilizados pela maioria dos laboratórios clínicos, apresentam limitações e são primariamente derivados de indivíduos Norte-americanos e europeus. O objetivo deste trabalho foi determinar os valores de referências para linfócitos $B$ e subpopulações de linfócitos T (CD4+, CD8+, naive, memória, regulatórias, $\mathrm{TCR} \alpha \beta$ and $\mathrm{TCR} \gamma \delta$ ) e células Natural Killers em doadores de sangue em Salvador-Bahia, Brasil. Resultados: A proporção de homens incluídos foi de $73.7 \%$ e média de idade em homens (34) e mulheres (35) foram similares. Para os linfócitos totais foram encontrados em ambos os gêneros, valores absolutos na ordem de 1.956 (1.060-4.186) células e 34\% para média relativa. Para linfócitos T CD4+ e T CD8+, os valores relativos foram de 51\% (20-62) e 24\% (9-28), respectivamente. Os mais altos índices de significância estatística encontrados foram alto percentuais de linfócitos $\mathrm{B}(p=0,03)$ em mulheres. Os resultados encontrados para outras populações 
celulares foram consistentes em relação a muitas populações de diferentes áreas geográficas.

Palavras-chave: Subgrupos de linfócitos, valores de referências, citometria de fluxo, Brasil, doadores de sangue.

\section{REFERENCES}

BAIN BJ. 1996. Ethnic and sex differences in the total and differential white cell count and platelet count. J Clin Pathol 49: 664-666.

Barnes PF, GRISSO CL, ABRAms JS, BAND H, REA TH AND ModLIN RL. 1992. Gamma delta T lymphocytes in human tuberculosis. J Infect Dis 165(3): 506-512.

BELKAYD Y. 2007. Regulatory $\mathrm{T}$ cells and infection: a dangerous necessity. Nat Rev Immunol 7: 875-888.

BISSET LR ET AL. 2004. Reference values for peripheral blood lymphocyte phenotypes applicable to the healthy adult population in Switzerland. Eur J Haematol 72: 203-212.

BORREGO LM ET AL. 2007. Células reguladoras. Rev Port Pneumol 13(3): 365-376.

Bottino C, Tambussi G, Ferrini S, Ciccone E, Varese P, Mingari MC, MoretTA L AND MoretTA A. 1988. Two subsets of human $\mathrm{T}$ lymphocytes expressing gamma/delta antigen receptor are identifiable by monoclonal antibodies directed to two distinct molecular forms of the receptor. J Exp Med 168(2): 491-505.

BUCLIN T ET AL. 2011. Development and validation of decision rules to guide frequency of monitoring CD4 cell count in HIV-1 infection before starting antiretroviral therapy. PLoS One 6(4): e18578.

Dattoli VCC, Freire SM, Mendonça LR, Santos PC, MeYer R AND AlCANTARA-NeVes NM. 2011. Toxocara canis infection is associated with eosinophilia and total IgE in blood donors from a large Brazilian centre. TM \& IH. Trop med and int health 16: 514-517.

FAILACE R. 2003. Hemograma: manual de interpretação. $4^{\mathrm{a}}$ ed., Porto Alegre: Artmed, cap. 1.

FELIX GES ET AL. 2010. Ancestry informative markers and complete blood count parameters in Brazilian blood donors. Rev Bras Hematol Hemoter 32(4): 282-285.

FERREIRA MU ET AL. 2000. Tendência secular das parasitoses intestinais na infância na cidade de São Paulo (1984-1996). Revista de Saúde Pública 34(6): 73-82.

FORBES WH, JOHNSON REAND CONSOLAZIO F. 1941. Leukopenia in Negro work-men. Am J Med Sci 201: 407-412.

HaN XMD et AL. 1997. Tumor Lymphocytes in Patients with Advanced Ovarian Cancer: Changes During in Vitro Culture and Implications for Immunotherapy. Gyn Oncologist 65(3): 391-398.

Hirahara K ET AL. 2006. The Majority of Human Periferal Blood CD4+cd25high Foxp3+ regulatory T Cells Bear Functional Skin-Homing Receptors. The J of Immunology 177: 4488-4494.
IBGE - Instituto BRAsileiro DE GEOGRAFIA E EstatísticA. 2010. Painel do Censo de 2010.

LEE BW ET AL. 1996. Age- and Sex-Related Changes in Lymphocyte Subpopulations of Healthy Asian Subjects: from Birth to Adulthood. Cytometry 26(1): 8-15.

LugadA ES ET AL. 2004. Population-based hematologic and immunologic reference values for a healthy Ugandan population. Clin Diagn Lab Immunol 11(1): 29-34.

Magalhães M, FARré L, FAtal P AND BittTencourt A. 2011. Imunofenotipagem de Linfócitos CD4, CD8 e CD25 FOXp3 periféricos de pacientes com dermatite infecciosa associada ao $H T L V-1$. Revista Ciências Médicas de Pernambuco 7(2): 19-22.

Ngowi B, Mfinanga SG, BruUn JN And Morkve O. 2009. Immunohaematological reference values in human immunodeficiency virus-negative adolescent and adults in rural northern Tanzania. BMC Infectious Diseases, p. 1-7.

NgOwi BJ, MfinANGa SG, BRUUn JN AND MorkVE O. 2008. Pulmonary tuberculosis among people living with HIV/ AIDS attending care and treatment in rural northern Tanzania. BMC Public Health 8: 341.

OCHS HD ET AL. 2007. "IPEX, FOXP3 and regulatory T-cells: a model for autoimmunity." Immunol Res 38(1-3): 112-121.

PANCham SP, BAIN BJ AND PUSPARAJAH T. 1999. When is neutropenia benign? Postgrad Doct Carib 18:146-152.

RIPPEY JJ. 1967. Leucopenia in West Indians and Africans. Lancet 2: 44.

SachdeVA M, Fischl MA, Pahwa R, SAChdeVa N AND PAHWA S. 2010. Immune exhaustion occurs concomitantly with immune activation and decrease in regulatory $\mathrm{T}$ cells in viremic chronically HIV-1-infected patients. J Acquir Immune Defic Syndr 54: 447-454.

SANTAGOSTINO A ET AL. 1999. An Italian national multicenter study for the definition of reference ranges for normal values of peripheral blood lymphocyte subsets in healthy adults. Haematologica 84(6): 499-504.

ShaHghasempour S, Gerami M AND ZinAT E. 2001. Enumeration of peripheral blood lymphocyte subsets in a healthy Iranian population. Arch Irn Med 4(2): 80-83.

TORGERSON TR AND OCHS HD. 2007. Regulatory T cells in primary immunodeficiency diseases. Curr Opin Allergy Clin Immunol 7(6): 515-521.

TSEGAYE A ET AL. 1999. Immunohematological Reference Ranges for Adult Ethiopians. Clin and Diag Lab Immunology 6(3): 410-414.

URquhart NE, CAPILDEO KD, SARgEANT LA, Wharfe G, HisADA M AND HANCHARD B. 2008. White blood cell counts in healthy Jamaican adults. West Indian Med J 57(2): 147-151.

WAKEMAN L ET AL. 2007. Routine Haematology Reference Ranges for Healthy Adults. Int J Lab Hematol 29: 279-283.

YeH JJ, CHEN SC, TENG WB, CHOU CH, HSIEH SP, LEE TL AND WU MT. 2010. Identifying the most infectious lesions in pulmonary tuberculosis by high-resolution multi-detector computed tomography. Eur Radiol 20(9): 2135-2145. 
